\title{
ECHR AND NATIONAL CONSTITUTIONAL COURTS ${ }^{* *}$
}

\begin{abstract}
Comprising fundamental rights and freedoms and establishing the effective control system, the European Convention on Human Rights (ECHR) encroaches upon the area that is traditional reserved for constitutional law. Although built on the doctrine reserved for international treaty law, the Convention goes beyond the traditional boundaries that exist between international and constitutional law. It has gradually infiltrated into the national legal systems. Constitutional courts have had the crucial role in this process. This paper will focus on the applicability of the ECHR in proceedings before national constitutional courts. Having in mind the jurisdiction of the national constitutional court, the ECHR may be applied in two ways: first, in the process of constitutional review by national constitutional courts and, second, in the process of deciding on constitutional complaints.
\end{abstract}

Key words: ECHR, constitutional court, ECtHR.

\section{Introduction}

The European Convention for the Protection of Human Rights and Fundamental Freedoms (ECHR) is indisputably a central reference text for the protection of fundamental rights in Europe. Having emerged on the ruins of Europe, its immediate aim was to give practical effect to certain rights and freedoms and to provide for their collective international implementation. Yet, this instrument was not primarily designed to create new substantive rights but to establish a new international mechanism which would enable individuals to initiate proceedings against their own states (Drzemczewski, 2004:7). The ECHR established a vigorous and solid foundation for the protection of human rights at the European level. The ECHR was opened for signature in 1950 and came into force in 1953. From that moment until the late 1980s, it was implemented only in West

\footnotetext{
*maja@prafak.ni.ac.rs
}

** The author acknowledges the grant of the MNTR 179046, for carrying out this research. 
European countries. In the 1950s and 1970s, West European states successively embraced a new constitutionalism (Stone Sweet, Keller, 2008:5). They considered the Convention to be an instrument for preventing future wars, opposing Communism and articulating a common European identity. After the collapse of Communism, the Convention played a crucial role in binding the East and the West. Back then, the Convention started its "second" life and was adopted in the countries of Central and Eastern Europe. Soon, the number of signatories to the Convention and members of the Council of Europe doubled.

In order to fully comprehend the significance of the Convention, we will observe the impact of the ECHR on the protection of human rights in the national legal system and to what extent it is implemented by the bodies in charge of protecting human rights. In particular, it would be interesting to examine its implementation before the national constitutional courts. In that context, we will first discuss the legal nature of the Convention. Then, we will examine the importance of the ECHR in the constitutional appeal procedure and in the constitutional review proceedings. Finally, we shall observe the application of the ECHR before the Constitutional Court of Serbia.

\section{The Legal Nature of the ECHR}

The ECHR, drafted under the patronage of the Council of Europe, is a multilateral treaty but it is an international treaty on human rights concluded between states for the benefit of individual users. "Unlike the 1948 Universal Declaration of Human Rights upon which it was founded, the ECHR represents more than a common standard of achievement" (Drzemczewski 2004:22). Unlike other similar international treaties on human rights, the ECHR defines legal measures to be undertaken in case there has been a breach of protected rights or freedoms. Furthermore, the Convention recognized an individual as an applicant before the European Court of Human Rights (ECtHR). The right of individual petition is a greatest novelty introduced by the ECHR. At the same time, the high contracting parties have agreed to observe and implement the decisions reached by the ECtHR in such proceedings.

Although the ECHR was originally considered to have established minimal standards for basic human rights, the ECtHR has interpreted the Convention rights in a progressive manner. According to the Court, the ECHR is not a static but a living instrument ${ }^{1}$, which must be interpreted in the light of present-day conditions. ${ }^{2}$ Unexpectedly, through the interpretation of the ECHR, the ECtHR jurisprudence gradually generated a new form of law which has developed into an evolving

1 Case of Tyrer v. United Kingdom (appl. no. 5682/72)

2 Case of Loizidou v. Turkey (appl. no. 15318/89) 
concept of "Convention law". It is law in substantial rather than formal sense. The law of the Convention is neither national nor international law; yet, it comprises elements of both. It is applied not only by the ECtHR but also by the Committee of Ministers of the Council of Europe and by national courts. Moreover, this body of law is binding not only for the signatory states but also for individuals in the field of civil rights and liberties, thus creating a new common European system which substitutes the individual system of each member state. Hence, the ECHR ceases to be a simple international treaty based on the principle of reciprocity and evolves into a normative treaty encompassing both international and national legal structures (Drzemczewski, 2004: 9). Therefore, the ECHR cannot be interpreted in the same manner as other multilateral synallagmatic treaties.

The sui generis nature of the ECHR is also emphasized in the jurisprudence of the ECtHR. The Court stated "that a purpose of the High Contracting Parties in concluding Convention was not to concede to each other reciprocal rights and obligations in pursuance of their individual national interests, but to realize the aims and ideals of the Council of Europe and to establish a common public order of the free democracies of Europe with the object of safeguarding their common heritage of political traditions, ideals, freedom and rule of law". ${ }^{3}$ In the Belgian Linguistic case, the Court pointed out that the general aim of the ECHR, laid down by the Contracting Parties, was to provide for an effective protection of fundamental human rights, which is certainly not only because of the historical context in which the Convention was concluded but also due to the social and technical developments in our age offering States ample options for regulating the exercise of these rights. Therefore, the Convention implies a just balance between the protection of the general interest of the Community and the observance of fundamental human rights while attaching particular importance to the latter. Finally, in the case of Loizidou v. Turkey, the Court described the ECHR as "a constitutional instrument of European public order".

Although the Convention does not contain any explicit rules on how contracting parties are to implement it, the ECHR now functions as a "shadow constitution", or a "surrogate charter of human rights", particularly in those states that do not have their own judicially enforceable Bills of Rights (Sweet Stone, 2009). Considering that the ECHR comprises a catalog of fundamental rights and freedoms and establishes the effective control system, the ECHR encroaches upon the area that is traditionally reserved for constitutional law. Although built on the doctrine of international treaty law, the Convention goes beyond traditional boundaries that exist between international and constitutional law. Nowadays, national judicial authorities in almost all contracting parties increasingly refer both to the ECHR and the national constitutions during their decision-making

3 Case Austria v. Italy (appl. no. 788/60) 
processes. Therefore, in order to consider the real nature of the ECHR, we should observe its impact on the national system of human rights.

\section{The ECHR in the proceedings before national constitutional courts}

The ECHR leaves to the High Contracting Parties to decide how to comply with the duty to observe the Convention provisions. It does not lay down for the contracting parties "any given manner for ensuring within their international law the effective implementation of any of the rights and freedoms guaranteed". ${ }^{4}$ As there are no international mechanisms which accurately define its status in the national law, each contracting party has chosen its own way of incorporating the ECHR into its legislation. Thus, there are various solutions. The ECHR commonly enjoys the status given to international treaties in general. It has supremacy over the national legislation but, in the hierarchy of legal documents, it is a document of a lower rank than the constitution. In the constitutions of some contracting states, international human rights' treaties have been given a special status (e.g. Article 10 of the Spanish Constitution). Only a few_contracting parties have acknowledged the constitutional status of the European Convention (e.g. Austria).

The attitude of the national constitutional system towards the ECHR was partly determined by its concept of human rights. If the national constitutional system has no comprehensively regulated human rights system, the Convention can be used to fill these gaps. The Convention thus compensates for the deficiencies in the national legal system of Austria, UK, and France. By contrast, Germany has a complete and accurate Bill of Rights incorporated in its Basic Law. Therefore, the role of the ECHR is to encourage the development of the national system.

The special character of the Convention is not reflected only in its status in the domestic legal system but also in its influence on the national human rights protection institutions, in particular constitutional courts. At first, national constitutional courts, as genuine defenders of national sovereignty, were reluctant to incorporate the ECHR into their national legal systems. The process was further aggravated by the fact that most countries did not recognize case law as a formal source of law. The resistance started yielding in the 1980s, and particularly in the past ten years of the $21^{\text {st }}$ century. Nevertheless, the ECHR has gradually infiltrated in the national human rights' protection systems. Constitutional courts have had a key role in this process. Being aware of the pervasive effect of the ECHR on human rights, they recognized that reliance on the Convention could strengthen their authority on the national level. Bearing in mind that the constitutional court is "the guardian of the Constitution" but also "the defender

4 Swedish Engine Drivers Union, Appl. no 5614/72 
of human rights and freedoms", the ECHR could be applied in two ways: first, in the process of constitutional review by the national constitutional court and, second, in the process of deciding on constitutional complaints.

\subsection{Constitutional review and the ECHR}

Constitutional review is one of the most important constitutional court competences. It may be defined as "a power of judicial bodies to set aside ordinary legislative or administrative acts if judges conclude that they conflict with constitution" (Vanberg, 2005:1). It is "the core competence of the constitutional judicature in Europe" (Stojanović, 2014:76). The constitutional review may take on two different forms: a priori (preventive) control, pertaining to the regulation which has not been put in place yet; and a posteriori (subsequent and thus repressive) control, pertaining to the regulation which has already been established.

Given that international treaties become part of the national legal system in the process of ratification, the prevailing opinion is that they may be the basis as well as the subject of constitutional review. It directly depends on their status in the national constitutional law; yet, all these issues may be observed as part of a broader concept: the relationship between the national and the international law. The judicial review of constitutionality of international treaties implies the assessment of their compliance with the Constitution, exercised by the Constitutional Court. This type of constitutional review should be exercised as a preventive (a priori) control.

Considering the fact that the European Convention is an international treaty (albeit of a suigeneris nature), it is subject to the same rules which apply to other international agreements. The Convention may be the subject or the basis for constitutional control, depending on its status in the national system.

In Austria, the ECHR has been granted the rank of constitutional law by an explicit constitutional norm. ${ }^{5}$ The fundamental rights enshrined in the ECHR have the same status and the same importance as other fundamental rights enshrined in the Austrian Constitution, which gives the Convention a unique position in relation to classical international treaties. The ECHR is directly applicable constitutional law and it is used as an instrument for the general judicial review of legal norms (pursuant to Articles 139 and 140 of the Federal Constitutional Law). Even though many states have envisaged the ECHR as a legal document of a lower rank than the constitution, the jurisprudence of national constitutional courts indicates that the ECHR is more frequently used as a constitutional control instrument than as the basis for constitutional review. Such practice stems from

5 Art. II of the amendment to the Federal Constitutional law, Federal Law Gazette 59/1964 
the fact that constitutional review of international treaties is a highly sensitive area of constitutional law. If the constitutional review of international treaties is undertaken, it should be exercised as an a priori control.

In the German system, according to Article 59 (2) of the Basic Law, the ECHR has been incorporated by virtue of a formal statute. Consequently, the Convention enjoys the status and rank of a federal statute. The Basic Law does not include explicit provisions on the constitutional review of international treaties. Nevertheless, the Federal Constitutional Court (FCC) has exercised this type of control in practice. The FCC considers that that international treaties may be subject to constitutional review by relying on the dualist transformation doctrine, which implies that review is made not of the treaty itself, but of the statute approving and transforming this agreement (Wildhaber, 1971: 335). Perceived in this manner, the constitutional review of international treaties has a character of an a priori control. The FCC took such a position considering the international complications that may arise in case a treaty which has already entered into forces is declared unconstitutional (Marković, 1973: 41). The constitutional review of the ECHR has never been initiated by competent authorities and it has never been the subject matter of the FCC adjudication. However, the FCC has used the ECHR as a basis for instituting a constitutional review.

In the Spanish Constitution, the ECHR has a "supra legislative" status, which means that it has been ranked above the domestic legislation but below the Constitution. Further, the relevant provisions of the Constitution state that the provisions pertaining to the fundamental rights and freedoms recognized by the Constitution should be construed in accordance with international treaties and agreements on human rights that have been ratified by Spain. The Constitutional Court has repeatedly maintained that the ECHR can encompass the content of constitutional rights, having a special relevance for the interpretation of those rights. The ECHR is frequently quoted in the Spanish constitutional case law. The ECtHR jurisprudence has had an extraordinary impact on the national judicature and inspired more than 500 judgments rendered by the Spanish Constitutional Court. Since international treaties cannot be amended or derogated by domestic legislation, the Constitutional Court ruled that national courts have to set aside the legislation which is incompatible with the ECHR. In case of doubt, they may raise a question of constitutionality asking the Constitutional Court to review the compatibility of domestic legislation with the fundamental rights protected by the ECHR and the Constitution (Caligiuri, Napoletano: 2010).

In Italy, the ECHR was ratified and incorporated into the Italian legal system by Law No. 848 of 4 August 1955, formally obtaining the rank of an ordinary law. The critical moment for applying the Convention in proceedings before the 
Constitutional Court was the constitutional revision in 2001. Since then, the jurisprudence of the Italian Constitutional Court contains a significant number of cases referring to the ECHR. In 2007, the Constitutional Court (for the first time) annulled a national statute on the grounds of being in contravention with the Convention. The Court held that the ECHR provisions must be taken into account as "interim rules", given the fact that the ECHR takes "the middle ground" in the domestic hierarchy of sources of law (ranking between the Constitution and ordinary legislation) and that it is used as an instrument for constitutional control the national legislation. Although the Italian Constitution does not expressly refer to the ECHR and the Convention rules do not automatically prevail over the domestic rules, the disputes involving conflicts between the ECHR and the domestic laws cannot be directly resolved by ordinary courts; they have to be referred to the Constitutional Court. Consequently, the legislator is bound by the ECHR, whose rules are an indirect parameter for constitutional review of domestic laws. ${ }^{6}$

Despite being one of the original signatories to the ECHR, France actually ratified the Convention in 1974. Since then, by virtue of Article 55 of the Constitution, the self-executing provisions of the Convention have a hierarchically superior position over both prior and subsequent conflicting legislation (Drzemczewski, 2004:71). Under the French Constitution, Constitutional Council has the authority to review statues and control their constitutionality. The Court exercises a preventive constitutional review, particularly in terms of the constitutional control of international treaties. Thus, Protocol No.6 to the ECHR was subject to constitutional review, initiated by President Mitterrand ${ }^{7}$. In a very brief decision, the Constitutional Council found that Protocol 6 to the ECHR concerning the abolition of death penalty contains no clause contrary to the Constitution. However, in the ensuing initiative taken by eighty-one members of the National Assembly, the Constitutional Council was invited to declare Article 4 of the French Abortion Law of 20 December 1975 unconstitutional and incompatible with Article 2 of the ECHR. As far as the ECHR is concerned, the Council unexpectedly made it clear that the incompatibility of legal rules provided in this treaty cannot be regarded as a case of unconstitutionality. According to Article 61 of the Constitution, the Council is authorized to decide on the conformity of statutes submitted to its examination with the Constitution. Therefore, the Council refused to incorporate the ECHR into the constitutional criteria for constitutional review.

6 Italian Constitutional Court, Decisions Nos. 348 and 349 of 2007

7 Decision No.85-188 DC du 22 Mai 1985 (http://www.conseil-constitutionnel.fr) 


\subsection{Constitutional complaint and the ECHR}

Constitutional complaint is a legal remedy that can be invoked chiefly for the violation of constitutional rights and liberties arising from individual administrative or judicial acts issued by public authorities. The constitutional complaint procedure before the national constitutional court is a specific point of reference which connects the two systems: the European and the national system. The ECtHR may decide on human rights' violation issues only after all domestic legal remedies, including the constitutional complaint, have been exhausted. The exhaustion of domestic remedies reflects the principle of subsidiarity, which provides that the international protection of human rights comes into play in case of deficiency on the part of the State concerned. Moreover, the effective system of resolving individual complaint submitted to the national constitutional court may be a national filter for legal cases before they are referred to the ECtHR.

The European and the national human rights' protection systems have much in common. The comparison may be based on the major elements, such as: eligibility to submit, legal grounds for submission, requirements for admissibility, and legal effects of respective rulings of competent courts (Nastić, 2012:243). The constitutional complaint, just like an individual application to the ECtHR, places an individual at the centre of legal protection and ensures an equal position by enabling an individual to pursue protection against a more powerful rival (the state). Whereas the subject matter of application is regulated by general rules, the proceedings before the Constitutional Court are explicitly and precisely regulated by the national legislation. It seems that national legal systems, in order to observe the rules of active procedural legitimacy (eligibility to submit), set much stricter conditions for lodging a constitutional complaint. Yet, both the European and the national system exclude actio popularis. Finally, a constitutional complaint is an instrument of subjective nature whereas an application to the ECtHR is an instrument of objective character because the subject matter of application may be either the applicant's personal/private interest or the general/public interest. In the comparative analysis of these two systems, we may also note clear difference in the effects of rendered judicial decisions. The Constitutional Court decisions have the cassation effect whereas the ECtHR judgments are essentially declarative and they cannot annul the decisions of the national court or another state authority.

Yet, as previously noted, pursuant to Article 46 of the ECHR, the High Contracting Parties are obliged to abide by the final judgments of the ECtHR in any case to which they are parties. It follows, inter alia, that any judgment where the Court establishes a breach of human rights imposes a legal obligation on the respondent State to redress the applicant by providing relevant monetary 
compensation (damages). Concurrently, the Court ruling implies an obligation of the respondent State to choose (under the supervision of the Committee of Ministers) the general and/or individual measures to be adopted in the national legal order to put an end to the violation found by the Court. ${ }^{8}$ Furthermore, pursuant to Article 1 of the Convention, in the process of ratifying the Convention, the Contracting States are obliged to ensure that their domestic legislation is compatible with the Convention. Consequently, the respondent State is to remove any obstacles in its domestic legal system that might prevent the applicant from being adequately redressed.

Although a large majority of constitutional courts declare themselves not to be bound by the ECtHR case law, they admit that it is one of their main sources of inspiration. In fact, the ECHR case law can be used as an additional instrument for interpreting and defining the content and scope of fundamental rights enshrined in national constitutions. Moreover, considering the rank given to the ECHR in Austria, a constitutional complaint may be lodged for the infringement of rights enshrined in the Convention. In Germany, under Article 93 (4a) of the Basic Law, a constitutional complaint may be filled by any individual claiming a violation of the fundamental human rights stemming from administrative/judicial activities of public authorities. It is clear that a constitutional complaint may not be based on a breach of rights enshrined in an international treaty even if it has been transposed into German law by a federal statute (Hoffmeister, 2006:9). Yet, in its Decision of 14 October 2004, the FCC stated that the guarantees provided by the ECHR, due to its status in the hierarchy of norms, "are not a direct constitutional standard of review in the German legal system. A complainant, therefore, cannot directly invoke the violation of a human right contained in the ECHR by lodging a constitutional complaint before the Federal Constitutional Court." 9 However, the Court held that the text of the Convention and the ECtHR case law serve, at the level of constitutional law, as guidelines for interpreting the content and determining the scope of fundamental rights and constitutional principles envisaged in the Basic Law. This does not lead to a restriction or reduction of fundamental rights protection that the individual enjoys under the Basic Law (BVerfGE 111, 307). The ECHR fosters a pan-European development of human rights protection. The Basic Law affords special protection to some core human rights envisaged in Article 1 (2). This norm, in conjunction with Article 59 (2), serves as the constitutional basis for the Constitutional Court obligation to take account of the Convention in the interpretation of fundamental rights in Germany. Accordingly, it may be possible to claim before the FCC that state organs

8 Case of Scozari Guinta v. Italy, appl. no. 39221/98, 41963/08, para 249.

9 BVerfGE 111, 307 
did not properly take into consideration the ECtHR judgments; this possibility falls within the scope of German fundamental rights ${ }^{10}$.

In Spain, a constitutional complaint (recurso de amparo) may be filed against any act of a public authority, except for an Act of Parliament. It is a highly effective means of legal protection of fundamental rights and freedoms (Danneman, 1994:151). The Spanish Constitution repeatedly notes that it is irrelevant to examine whether international texts binding for Spain are being observed per se or not, but it is essential to supervise the observance and any infringement of constitutional provisions related to fundamental human rights and public freedoms which are protected in the constitutional complaint procedure. The jurisprudence of the Spanish Constitutional Court shows that the Court strictly observes the case law established by the ECtHR as a general rule. Thus, the Court has interpreted some of the fundamental rights listed in the 1978 Spanish Constitution as guidelines laid down by the ECtHR case law (Report Spain, 2014).

\section{The ECHR and the Constitutional Court of Serbia}

The State Union of Serbia and Montenegro ratified the ECHR as well as Protocols No. 1, 4, 6, 7, 12 to the Convention on 26 December 2003, and the Convention entered into force on 3 March 2004. In Serbia, the Convention was ratified almost 50 years later than in West European countries, which may be justified by the fact that our country (Yugoslavia) used to be part of the communist/socialist block. The ECHR was ratified almost 10 years later than in the neighboring countries, which may be attributed to insufficient commitment to human rights' protection issues. In order to evaluate the importance of the ECHR in our constitutional system, we will examine the legal nature of the Convention, its status in the national legislation and its application before the Constitutional Court of Serbia.

Like many other constitutions, the Serbian Constitution does not explicitly regulate the status of the ECHR. Yet, it has the same status as other international treaties. The status of international treaties is part of materia constitutionis in the Serbian Constitution, which is based on the monistic concept resting on the primacy of international law over the national law.

The Constitution (2006) specifies that ratified international treaties and generally accepted rules of international law shall be an integral part of the legal system of the Republic of Serbia. Ratified international treaties may not be in noncompliance with the Constitution, whereas the laws and other general acts enacted in the Republic of Serbia may not be in noncompliance with the ratified international treaties and generally accepted rules of international law (Article

10 Case of Görgülü v. Germany (appl. No. 74969/01) 
194). Thus, in the hierarchy of legal acts, international treaties are below the Constitution but above the laws and other general acts enacted in Serbia. The Constitutional Court shall decide on compliance of laws and other general acts with the Constitution, generally accepted rules of the international law and ratified international treaties, and compliance of ratified international treaties with the Constitution (Art. 167).

It should be noted that, under the Constitution, generally accepted rules of international law and ratified international treaties are an integral part of the legal system in the Republic of Serbia and that they are directly implemented (Art. 16). This primarily implies that the decisions of the Constitutional Court and all other courts and state authorities may be based on generally accepted rules of international law and ratified international treaties. But, direct implementation of international treaties is limited only to those regulating human rights, including the ECHR. As far as the Convention is concerned, the direct implementation refers to the provisions which are suitable for direct implementation. Further, the Constitution stipulates that provisions on human and minority rights should be interpreted to the benefit of promoting values of a democratic society, in compliance with valid international standards on human and minority rights, as well as the practice of international institutions supervising their implementation (Art. 18). Finally, Article 22 of the Constitution provides that everyone has the right to judicial protection in case any breach of their human or minority rights guaranteed by the Constitution have been violated or denied, as well the right to remove the consequences arising from the violation. Therefore, the protection of fundamental human rights and freedoms is primarily exercised within the framework of the national judicial system, including the constitutional judicial protection, but such protection may also be pursued before international institutions, such as the ECtHR. All the aforementioned articles of the Constitution make a normative framework for incorporating the ECHR into the national legal system.

With reference to the topic of this article, it is relevant to observe the activities of the Constitutional Court of Serbia and examine how the ECHR is applied in the process of constitutional review and in the process of deciding on constitutional complaints.

\subsection{Constitutional review}

Under the Serbian Constitution, the Constitutional Court has jurisdiction to rule on: the compliance of laws and other general act with the Constitution, generally accepted ruled of international law and ratified international treaties; the compliance of other general acts with the law; the compliance of statues and 
general acts of autonomous provinces and local self-government units with the Constitution and the law; and the compliance of general acts of organizations with delegated public powers, political parties, trade unions, civic associations and collective agreements with the Constitution and the law. (Art. 167)

In the process of exercising the abstract constitutional review, the Constitutional Court intervenes by removing the legislative solutions and provisions of by-laws and other general acts which do not comply with the Constitution, generally accepted rules of international law and ratified international treaties. This implies that the international treaty may be subject to and the basis for constitutional review. Under the 2006 Constitution, the Constitutional Court retained the a posteriori control as a dominant form of control. Pursuant to Article 169 of the Constitution, there is also a possibility of instituting the preventive ( $a$ priori) control. In general, the system of preventive control gives rise to many questions and dilemmas. The only good point is the possibility of applying the preventive (a priori) control in the course of establishing the constitutionality of international treaties.

The ECHR is used as a basis of constitutional review. The Constitutional Court has been referring in its jurisprudence to the ECHR and the ECtHR opinions. Some of the relevant Constitutional Court decisions worth mentioning in this context are the ruling on the procedure for distributing mandates (seats) in the National Assembly ${ }^{11}$ and the decision to repeal the so-called "blank resignation" institute $^{12}$ (Report Serbia, 2014).

The Constitutional Court has also rendered a decision prohibiting the work of a civil association, "The Fatherland Movement Obraz",13 expressing the view that the constitutionally guaranteed freedoms of opinion, expression and assembly may not be exercised by depriving other people or groups of those freedoms. In the case of IUz 147/2012, the disputed legal provision specified a statutory time limit for filing a motion for retrial. The Constitutional Court found that this provision was not in compliance with the the Constitution and ratified international treaty; consequently, in case the ECtHR subsequently renders a judgment finding a violation, the disputed provisions will bring into question the constitutionally guaranteed right to judicial protection.

Apart from reviewing the substantive and procedural aspects of the aforementioned constitutional provisions, the Constitutional Court has also called attention to the significance of the "quality" of laws, primarily in order to en-

11 The Act on the Election of MPs (Official Gazette of the Republic of Serbia No. 35/00)/ Decision in the case of IUz-42/2008 of 14 April 2011

12 The Local Elections Act -Decision in the Case of IU 52/2008

13 Decision in the case of VIIU-249/2009 of 12 June 2012 
sure the observance of the principle of legal certainty. Thus, the Constitutional Court has also considered whether the requirements arising from the legal term "prescribed by law" have been met. Thus, relying on the concept of "law" provided within the meaning of Articles 9, 10 and 11 of the Convention and interpreted in the ECtHR case law as including both legislative acts and other general acts, the Court also considered the fact that the "law" must meet the requirement of being formulated with sufficient precision to enable everyone to adjust their demeanour in accordance with the consequences, which equally apply to all and are available by virtue of publication or some other means of public communication (Report Serbia, 2014).

\subsection{Constitutional complaint and the ECHR}

The 2006 Constitution of Serbia recognized a constitutional complaint as an extraordinary legal instrument for the protection of human rights. It may be lodged against individual general acts or actions performed by state bodies or organizations exercising delegated public powers which violate or deny human or minority rights and freedoms guaranteed by the Constitution, provided that all other legal remedies for the protection have already been applied or have not been specified. This legal instrument is a valuable addition that rounds up the national human rights protection system. In the view of the Constitutional Court, the protection of "all constitutionally guaranteed human and minority rights and freedoms, both individual and collective, regardless of their position in the Constitution and whether they are explicitly integrated in the Constitution or implemented in the constitutional judicial system via international treaties" shall be exercised before the Constitutional Court. ${ }^{14}$

The Constitutional Court jurisprudence includes many decisions where the Court has explicitly referred to the ECHR and ECtHR case law. For example, in the case of Uz 227/2008 of 9 July 2009, when deciding on the presumption of innocence, the Court referred to the ECtHR case law which specifies that the presumption of innocence shall be violated if a judicial decision or a statement by a public official concerning a person charged with a criminal offence reflects an opinion that he is guilty even before he has been officially proven guilty. In the case of Uz 88/2008 of 1 October 2009, the Court established that the departure from the constitutional right to inviolability of confidentiality of all means of communication in the case at issue was in compliance with the Constitution and the law. The allegations concerning the violation of the complainant's right to

14 The Constitutional Court's Views on the Preliminary Constitutional Complaint Review Procedure of 30 October 2008 and 2 April 2009. 
inviolability of the confidentiality of means of communication, as an aspect of the right to privacy enshrined in Article 8 of the ECHR, were unjustified.

In addition, in the constitutional review of the complaint filed by non-reappointed judges against the High Judicial Council Decision of 25 December 2009 concerning the termination of their judicial offices as of 31 December 2009 pursuant to the new Judiciary Act ${ }^{15}$, the Constitutional Court rendered a pilot decision upholding the complaint. The Court stated that the complainants should have been provided with all the procedural guarantees enshrined in the right to a fair trial, including rendering all individual and reasoned High Judicial Council decision that should have specified the individual reasons for the non-reappointment. The Court based its view, inter alia, on the ECtHR case law referring to Article 6, paragraph 1 of the ECHR (right to a fair trial), as well as on the view that the Court expressed in a number of judgments under which the absence of a reasoning may hinder access to justice if it precludes effective recourse to the appeal procedure due to insufficient grounds which the first instance decision is based on.

The Constitutional Court gradually aligned its jurisprudence with the view taken by the ECtHR in its judgments against the Republic of Serbia ${ }^{16}$ stating that comprehensive constitutional judicial protection should entail both the establishment of breach and redress including both pecuniary and non-pecuniary damages.

Finally, it should be noted that the ECtHR is of the opinion that a constitutional complaint should, in principle, be considered as an effective domesic remedy within the meaning of Article $35 \S 1$ of the Convention in respect of all application introduced as of 7 August 2008, ${ }^{17}$ when the Constitutional Court adopted the first decision on the merits of the filed complaints, including the very first decision establishing a violation of the Constitution.

\section{Conclusion}

The constitutional protection of individual rights has been developed in all countries that have adopted the concept of a written constitution. After the Second World War, the role of the constitutional court has become significant in this area, especially in the constitutional complaint proceedings. Concurrently, an ongoing process of internationalization of human rights was under way. In Europe, the 1950 European Convention on Human Rights enumerates the basic

15 Official Gazette of the Republic of Serbia No. 116/08

16 For example, the case of Vlahović v. Serbia, R. Kačapor and Others v. Serbia

17 Case of Vinčić vs. Serbia (appl. Nos.44698/06, 44700/06, 44722/06 et. al) 
civil and political rights of every person within the jurisdiction of any member state and establishes the procedural framework to vindicate those rights. The importance of the ECHR lies not only in the scope of envisaged human rights but also in the supranational control mechanism aimed at examining and remedying any violation of these rights, and ensuring compliance with the obligation imposed therein. In spite of certain weakness, in the period of over sixty years of its application (since 1953 when it came into force), the ECHR has grown into a strongest and most effective human rights treaty. Hence, the Convention has become a constitutional instrument of the European public order.

The ECHR and its protection system are not designed to substitute national human rights system. The European system is subsidiary, designed to handle all cases that have evaded the rigorous scrutiny of national constitutional courts. In other words, responsibility for adequate protection of individual rights no longer lies within the exclusive province of national courts but has to be shared with at least one supranational structure. Being aware of the fact that they do not have "the final say" in field of human rights protection, constitutional courts have accepted the standards laid down in the ECHR and the ECtHR case law on this matter. Furthermore, the effective operation of the national legal system and the European system of human rights can be ensured only through cooperation between national constitutional courts and the ECtHR.

Constitutional courts may apply the ECHR and the ECtHR case law in two ways: through direct implementation of applicable provision of the ECHR, and by accepting the ECtHR interpretation of its contents, basic principles and institutes as construed in the ECtHR case law.

\section{References}

Caligiri, A. Napoletano, N. The application of the ECHR in the domestic systems. (retrieved 30 June 2015 from https://www.academia.edu/633695/The_Application_of_the_ECHR_in_the_Domestic_Systems)

Danneman,G.(1994). Constitutional Complaints: The European Perspective. International and Comparative Law Quarterly. 43. 142-153

Drzemczewski, A. (2004). European Human Right Convention in Domestic Law-a comparative study, Oxford

Hoffmeister, F. (2006). Germany: Status of ECHR in domestic law. Int J. Constitutional law. 4 (4). 722-731

Marković, R. (1973). Pokretanje ustavnog spora o ustavnosti normativnih akata. Beograd 
Nastić, M. (2012). Komparativna analiza evropskog i sistema zaštite ljudskih prava u postupku po ustavnoj žalbi. Zbornik radova Pravnog fakulteta u Nišu. 63. $243-260$

Stojanović, R. (2014). Pokretanje normativne kontrole prava u evropskom modelu ustavnog pravosuđa. Zbornik radova Pravnog fakulteta u Nišu. 67. 59-78

Sweet Stone, A., Keller, H. (2008). A Europe of Rights: The Impact of the ECHR on National Legal Systems, Oxford

Sweet Stone, A.(2009). On the Constitutionalisation of the Convention: The European Court of Human Rights as a Constitutional Court. (retrieved from http:// digitalcommons.law.yale.edu/fss_papers/71/; 28 June 2015)

Vanberg, G. (2005). The Politics of Constitutional Review in Germany, Cambridge XVIth Congress of the Conference of European Constitutional Courts, National report of Serbia (retrieved from https://www.vfgh.gv.at/cms/vfgh-kongress/ downloads/landesberichte/LB_serbie_EN.pdf ; 30 June 201530 June 2015)

XVIth Congress of the Conference of European Constitutional Courts ,National Report of Spain (retrieved from https://www.vfgh.gv.at/cms/vfgh-kongress/ downloads/landesberichte/LB-Espagne-EN.pdf; 30 June 2015)

Wildhaber, L.(1971). Treaty-Making Power and Constitution. An international and comparative study. Helbing and Lichtenhahn 


\section{Др Маја Настић, \\ Доцент Правног факултета, Универзитет у Нишу}

\section{ЕВРОПСКА КОНВЕНЦИЈА И УСТАВНИ СУДОВИ}

\section{Резиме}

Најразвијенији међународни систем заштите људских права регионалног карактера данас функционише у оквиру организације Савета Европе и под окриљем Европске конвенције за заштиту људских права и основних слобода. Европска конвенција јесте међународни уговор, али међународни уговор sиі generis. Та специфичност односи се на само на форму, већ и на суштину онога што представља и тиче се интерпретације права и слободе гарантованих њоме. Иако изграђена на доктрини међународног уговорног права, Конвенција несумњиво задире у област која је традиционално резервисана за уставно право, представљајући својеврсну спону унутрашњег и међународног права. Тиме, Европска конвенција може да понесе епитет уставног инструмента европског јавног поретка, како је то и указао Европски суд за људска права у својој пракси.

Став националног уставног система према Европској конвенцији значајним делом је био одређен тиме како је област људских права регулисана на унутрашњем плану. Кључну улогу у имплементацији Конвенције у унутрашњим правним системима одиграли су национални уставни судови, у тренутку када су постали свесни прожимајућег ефекта Конвенције и њеног свеукупног значаја за развој људских права. Осим тога, ослањањем на Конвенцију препозната је могућност да уставни судови ојачају своју ауторитет на унутрашњем плану.

Европска конвенција налази своју примену у поступку пред националним уставним судовима приликом спровођења нормативне контроле, као њихове основне надлежности.

Одлучивање националног уставног суда по уставној жалби појављује се као специфична "тачка везивања" националног заштитног система и система, који се успоставља на основу Конвенције и отвара најшире могућности за њему примену, посебно ако се има у виду да је уставна жалба последње правно средство које треба искористити пре евентуалног обраћања Европском суду. Примена Европске конвенције у националним уставним системима, без обзира на спещифичности уставних решењ а иазрађених система правне заштите, довела је до тога да овај међународноправни акт превазиђе обележја обичног 
међународног уговора заснованог на репципроцитету, већ да добије обележја нормативног акта и уставни значај у разумевању основних људских права у унутрашњем систему.

Кључне речи: Европска конвенција за заштиту људских права и основних слобода, Европски суд за људска права, Уставни суд. 